\title{
EFEKTIFITAS PEMBELAJARAN KONTEKSTUAL UNTUK MENINGKATKAN PRESTASI BELAJAR MATERI LUAS BANGUN DATAR KELAS VI DI MIN MALANG I
}

\author{
Suroto $^{1}$
}

\begin{abstract}
One of the causes of those unsuccessfull students is the monotonous learning model. The learning process of the concept, it cannot well associate the abstract ideas to the real world. One of the learning models that can solve this problem is the contextual learning. The procedures of the contextual learning done in this research involve the process of: (1) exploring and using the students' concept which have been achieved by the students in the opening learning; (2) creating a study society in mastering new concepts; (3) utilization of learning medias in learning process; (4) reflection of the concepts which have been studied; and (5) testing the concept acquisition by personal student. From this results, if it use the contextual learning model, the students' achievement will increase.
\end{abstract}

Keywords: Contextual Learning, song of flat structure, various table of flat structure, Learning Achievement

\section{A. Pendahuluan}

Menurutteorikognitifpsikologiperkembanganyangdikemukakan oleh Jean Piaget menyatakan bahwa anak umur 7 - 12 tahun berada pada tahap operasional kongkrit (concrete operational stage). Pada tahap ini anak dapat melakukan penalaran logis menggantikan pemikiran intuitif sejauh pemikiran dapat diterapkan ke dalam contoh-contoh yang spesifik atau kongkrit. Anak dapat mengelompokkan secara memadai, melakukan pengurutan, menangani konsep angka, tetapi proses pemikirannya diarahkan pada kejadian riil yang diamati anak (Hergenhahn: 2012: 320).

Pembelajaran matematikahendaknya dimulaidengan pengenalan masalah yang sesuai dengan situasi (contextual problem). Dengan mengajukan masalah kontekstual, peserta didik secara bertahap dibimbing untuk menguasai konsep matematika, (Mendiknas, 2006:

1 Guru MIN Malang I 
Suroto - Efektifitas Pembelajaran Kontekstual untuk ...

416) Pembelajaran matematika hendaknya mengaitkan dengan topik sebelumnya. Materi prasyarat harus dikuasai dengan baik sebelum mempelajari materi berikutnya. Materi harus diajarkan bertahap mulai dari materi kongkrit, semi kongkrit dan akhirnya materi yang abstrak.

Dalam PP Nomor 32 tahun 2013 pasal 19 disebutkan bahwa proses pembelajaran pada satuan pendidikan diselenggarakan secara interaktif, inspiratif, menyenangkan, menantang, memotivasi peserta didik untuk berpartisipasi aktif, serta memberikan ruang yang cukup bagi prakarsa, kreativitas, dan kemandirian sesuai dengan bakat, minat, dan perkembangan fisik serta psikologis. (Permen 32 Tahun 2013 :10) Pemanfaatan alat peraga dalam pembelajaran merupakan upaya guru dalam memenuhi harapan peraturan pemerintah tersebut. Alat peraga membantu siswa dalam menguasai konsep-konsep matematika yang abstrak dan dapat menurunkan tingkat keabstrakan konsep matematika. Hal ini senada dengan apa yang disampaikan Middleton \& Goepfert (1996) bahwa matematika hendaknya realistis dan menarik, (Permen 32 Tahun 2013: 441)

Setelah mengadakan pembicaraan dengan guru pemegang mata pelajaran matematika kelas VI di MIN Malang I ditengarai bahwa ketidaktuntasan siswa dalam belajar matematika tentang luas bangun datar disebabkan oleh dua hal, yaitu pertama, kekurangmampuan siswa dalam menentukan bangun datar sederhana pembentuk bangun gabungan dan Kedua, siswa lupa dengan rumus bangun datar. Masalah pertama diatasi dengan penggunaan meja berbagai bentuk bangun datar, sedangkan masalah kedua diatasi dengan dibuatkannya lagu dengan syair tentang rumus-rumus luas bangun datar.

Dalam proses penelitiannya, siswa mengkonstruk pengetahuan yang telah dimiliki dengan ditampilkannya lagu tentang luas bangun datar. Hal ini dilakukan sesuai dengan apa yang disampaikan pakar teori pendidikan dari jaman Plato hingga Piaget dimana musik betulbetul dapat mencerminkan dan mengekspresikan proses pematangan. Pematangan berkembang dari suatu proses lebih kompleks ketika menghadapi informasi baru, ketika memeriksa implikasi dan potensinya terhadap latar belakang pengalaman terdahulu, kemudian mengintegrasikannya ke dalam suatu kesatuan yang lebih kompleks dan berimbang (Campbell. 2002: 246) 
Selain itu, siswa diberi pengalaman langsung berupa mengukur panjang dan lebar meja, memanfaatkan rumus luas yang telah mereka pelajari pada kelas sebelumnya, dan menghitung luas meja tersebut berdasarkan data hasil pengukuran yang mereka dapatkan. Siswa diharapkan dapat memanfaatkan pengalaman yang mereka dapatkan dalam memecahkan masalah yang mereka hadapi. Hal ini sesuai dengan teori belajar observasional yang dikemukakan oleh Miller dan Dollard (1941) tentang pembelajaran observasional yang disempurnakan oleh Bandura (1960) (Hergenhahn: 2012 360361). Menurut ahli tersebut bila pembelajaran menggunakan peraga diupayakan untuk menggunakan tahapan penggunaan alat peraga, yaitu penggunaan benda-benda kongkrit, menggunakan tiruan benda, gambar benda, dan tahap tertinggi adalah simbol benda.

Rumusan masalah pada penelitian ini adalah : 1) Bagaimana efektifitas pembelajaran kontekstual untuk pembelajaran matematika materi luas bangun datar? dan 2) Adakah perbedaan prestasi belajar matematika pada materi luas bangun datar pada siswa sebelum dan sesudah mengikuti pembelajaran kontekstual?

Tujuan penelitian ini adalah : 1) Memahami efektifitas pembelajaran kontekstual dalam pembelajaran matematika materi luas bangun datar dan 2) Memahami perbedaan prestasi belajar matematika pada materi luas bangun datar pada siswa sebelum dan sesudah mengikuti pembelajaran kontekstual.

Prestasi belajar dalam penelitian ini Menurut Kamus Besar Bahasa Indonesia (KBBI) online menyatakan bahwa prestasi belajar adalah penguasaan pengetahuan atau keterampilan yg dikembangkan melalui mata pelajaran, lazimnya ditunjukkan dengan nilai tes atau angka nilai yg diberikan oleh guru (Depdiknas. 2008).

Menurut ( $T u^{\prime} u$ 2004:75) menyatakan bahwa prestasi merupakan hasil yang dicapai seseorang ketika mengerjakan tugas atau kegiatan tertentu (Tulus : 2004). Sementara itu Andrews, Saklofske \& Jansen, 2001; Haladyna, 2002; Smith, 2001 dalam Santrock 2011: 606 menyatakan bahwa tes prestasi dimaksudkan untuk mengukur apa yang telah dipelajari atau keahlian apa yang telah dikuasai murid. (wibowo: 2011).

Robert L. Ebel, 1979 dalam Azwar 2013:14 menyatakan bahwa fungsiutama tes prestasi di kelas adalah mengukur prestasi belajar para 
siswa merupakan suatu kesalahfahaman. Sesungguhnya prosedur tes guna mengukur prestasi mengandung nilai-nilai pendidikan yang lebih akurat (valid) dan lebih dapat dipercaya (reliabel). Hasil tes tersebut digunakan dalam memperoleh kesimpulan yang lebih pada tempatnya, (Saifuddin. 2013:14).

Dari definisi-definisi yang dikemukakan para ahli di atas dapat disimpulkan bahwa prestasi belajar merupakan hasil usaha belajar yang dikuasai siswa secara akurat dan dapat dipercaya yang dicapai dalam bentuk nilai untuk memperoleh kesimpulan yang tepat.

Prestasi belajar merupakan hal yang tidak dapat dipisahkan dari kegiatan belajar karena kegiatan belajar merupakan proses, sedangkan prestasi merupakan hasil dari proses belajar. (Wandini 2008:11). Menurut Slameto (2010:54) bahwa faktor yang mempengaruhi belajar digolongkan menjadi dua, yaitu faktor intern dan faktor ekstern, (Slameto, 2010: 54)" Faktor intern merupakan faktor yang ada dalam diri individu yang sedang belajar. Ada tiga faktor yang mempengaruhi belajar dari dalam diri individu, yaitu: faktor jasmaniah, faktor psikologis, dan faktor kelelahan.

Faktor intern menurut Dimyati dan Mujiono (2009:238-247) bahwa belajar siswa dipengaruhi oleh: (1) sikap terhadap belajar; (2) Motivasi belajar; (3) Konsentrasi belajar; (4) Mengolah bahan belajar; (5) Menyimpan perolehan hasil belajar; (6) Menggali hasil belajar yang tersimpan; (7) Kemampuan berprestasi atau unjuk belajar; (8) Rasa percaya diri; (9) Intelegensi dan keberhasilan belajar; (10) Kebiasaan belajar; dan (11) Cita-cita siswa (Dimyati dan Mujiono. 2009: 236-247)

Upaya yang dapat dilakukan guru dalam mengoptimalkan faktor intern peserta didik adalah: 1) berfikir positif terhadap kondisi yang dihadapi, 2) menciptakan suasana yang menggembirakan dalam belajar, 3) pemberian selingan beberapa menit saat belajar untuk mengembalikan konsentrasi belajar (ice breaking), 4) menempatkan posisi peserta didik sebagai subyek belajar, 5) memberikan teknik belajar dalam menyimpan perolehan belajar, 6) memberikan teknik belajar dalam upaya menggali hasil belajar, 7) memberi kesempatan peserta didik dalam melakukan unjuk hasil belajar, 8) pemberian kesempatan sebagai upaya memunculkan rasa percaya diri peserta didik, 9) peserta didik dibiasakan memecahkan masalah sebagai upaya mengasah intelegensi yang dimilikinya, 10) pemberian penghargaan 
atau hukuman sebagai upaya mengoptimalkan kebiasaan belajar yang baik, 11) mengaitkan pemilikan cita-cita dengan kemampuan berprestasi dalam membangkitkan keberanian bereksplorasi.

Faktor ekstern merupakan faktor yang ada di luar individu. Faktor ekstern dikelompokkan menjadi tiga faktor, yaitu faktor keluarga, sekolah, dan masyarakat. Faktor keluarga berkaitan dengan cara orang tua mendidik, relasi antara anggota keluarga, suasana rumah tangga, keadaan ekonomi keluarga, dan pengertian orang tua, (Ni' am, 2013). Faktor sekolah berkaitan dengan metode mengajar, kurikulum, relasi guru dengan siswa, relasi siswa dengan siswa, disiplin sekolah, alat pelajaran, waktu sekolah, keadaan gedung, metode belajar, dan tugas rumah. Sedangkan faktor masyarakat berkaitan dengan kegiatan siswa dalam masyarakat, mass media, teman bergaul, dan bentuk kehidupan masyarakat.

Materi matematika SD/MI menurut Kurikulum 2006 untuk luas bangun datar mulai muncul pada kelas III semester 2 yang membahas tentang luas persegi dan persegi panjang. Kelas IV semester 1 tentang luas segitiga dan jajar genjang. Kelas $\mathrm{V}$ semester 1 tentang luas trapesium dan layang-layang. Kelas VI membahas luas lingkaran dan luas segi banyak yang merupakan gabungan bangun datar sederhana, (Permendiknas no.22 2006: 423-429). Kalau dicermati dari materi tentang luas bangun datar ini terlihat bahwa pembahasan materi luas bangun datar tidak langsung dibahas dalam satu rangkaian pembelajaran, melainkan bertahap dengan berbeda kelas.

Urutan pembahasan materi luas tersebut berdasarkan tingkat kelas tersebut berkaitan dengan tingkat kesulitannya. Selain itu juga berkaitan dengan proses pembentukan rumus dari luas bangun datar tersebut. Luas persegi panjang yang muncul pada kelas III semester 2 sebagai materi prasyarat dalam proses menemukan rumus luas segitiga dan jajar genjang yang ada pada kelas IV semester 1 . Begitu juga dengan proses penemuan rumus luas pada kelas V dan kelas VI.

Pengertian pembelajaran kontekstual banyak didefinisikan oleh para ahli. Diantaranya adalah Johnson yang merumuskan bahwa pembelajaran kontekstual merupakan proses pendidikan yang bertujuan membantu siswa melihat makna dalam bahan pelajaran yang mereka pelajari dengan cara menghubungkannya dengan konteks lingkungan pribadi dan sosialnya, melakukan hubungan 
yang bermakna, mengerjakan pekerjaan yang berarti, mengatur cara belajar sendiri, bekerja sama, berfikir kritis dan kreatif, merawat pribadi siswa, mencapai standar yang tinggi, dan menggunakan asesmen autentik, (Nurhadi dkk. 2009:13)

Menurut Bern dan Erickson (2001: 2) bahwa pembelajaran kontekstual merupakan konsep belajar dan mengajar yang membantu guru mengaitkan antara materi yang diajarkannya dengan situasi dunia nyata siswa dan mendorong siswa membuat hubungan antara pengetahuan yang dimilikinya dengan penerapannya dalam kehidupan mereka sebagai anggota keluarga, warga negara, dan pekerja.

Sementara itu menurut Hull's dan Sounders (1996:3) menjelaskan bahwa pembelajaran kontekstual, siswa menemukan hubungan penuh makna antara ide-ide abstrak dengan penerapan praktis dalam dunia nyata. Siswa menginternalisasi konsep melalui penemuan, penguatan, dan keterhubungan. Pembelajaran kontekstual menghendaki kerja dalam sebuah tim baik di kelas, laboratorium. Guru mendesain lingkungan belajar yang merupakan gabungan beberapa bentuk pengalaman untuk mencapai apa yang diinginkan.

Berdasarkan ketiga ahli di atas, dapat disimpulkan bahwa pembelajaran kontekstual merupakan pembelajaran yang menghubungkan ide-ide abstrak dengan dunia nyata agar siswa dapat menemukan makna dalam materi yang dipelajarinya.

Komponen pembelajaran kontekstual yang disampaikan Nurhadi (2004:31) ada tujuh yaitu: (1) Konstruktivisme (Constructivism), (2) Bertanya (Questioning), (3) Menemukan (Inquiry), (4) Masyarakat belajar (Learning Community), (5) Pemodelan (Modeling), (6) Refleksi (Reflection), dan (7) Penilaian sebenarnya (Authentic Assessment.

Pembelajaran kontekstual dapat digunakan untuk meningkatkan prestasi belajar dengan menerapkan prinsip dikemukakan oleh Nurhadi (2009:24) meliputi: 1) merencanakan pembelajaran sesuai dengan kewajaran perkembangan mental siswa; 2) membentuk kelompok belajar yang saling tergantung; 3) menyediakan lingkungan yang mendukung pembelajaran mandiri; 4) mempertimbangkan keragaman siswa; 5) memperhatikan multi-intelegensi siswa; 6) menggunakan teknik-teknik bertanya dalam meningkatkan pembelajaran siswa; dan 7) menerapkan penilaian autentik. 
Pembelajaran kontekstual yang digunakan guru harus dibuat persiapan yang matang dengan memperhatikan prinsip-prinsip di atas dan komponen-komponen yang telah di jelaskan di atas. Guru harus mampu memprediksi kemungkinan-kemungkinan yang terjadi dan upaya untuk mengatasi hal yang tidak diinginkan.

Guru harus cermat dalam membuat perencanaan mulai dari langkah pembukaan, kegiatan inti, hingga kegiatan penutup. Kegiatan pada tiap langkah juga harus berpandu pada Peraturan Menteri Pendidikan Nasional Republik Indonesia Nomor 41 tahun 2007 tentang Standar Proses untuk Satuan Pendidikan Dasar dan menengah.

Dalam lampiran Standar Proses romawi II tentang perencanaan proses pembelajaran pada huruf B yang membahas Rencana Pelaksanaan Pembelajaran (RPP) dinyatakan bahwa kegiatan pembelajaran terdiri dari pendahuluan, inti, dan penutup. Pendahuluan merupakan kegiatan awal dalam suatu pertemuan pembelajaran yang ditujukan untuk membangkitkan motivasi dan memfokuskan perhatian peserta didik untuk berpartisipasi aktif dalam proses pembelajaran.

Kegiatan inti merupakan proses pembelajaran untuk mencapai KD. Kegiatan pembelajaran dilakukan secara interaktif, inspiratif, menyenangkan, menantang, memotivasi peserta didik untuk berpartisipasi aktif, serta memberikan ruang yang cukup bagi prakarsa, kreativitas, dan kemandirian sesuai dengan bakat, minat, dan perkembangan fisik serta psikologis peserta didik. Kegiatan ini dilakukan secara sistematis dan sistemik melalui proses eksplorasi, elaborasi, dan konfirmasi.

Kegiatan penutup merupakan kegiatan yang dilakukan untuk mengakhiri aktivitas pembelajaran yang dapat dilakukan dalam bentuk rangkuman atau kesimpulan, penilaian dan refleksi, umpan balik, dan tindak lanjut.

\section{B. Metode Penelitian}

Pendekatan yang digunakan dalam penelitian ini adalah pendekatan kuantitatif. Nilai siswa tersebut merupakan hasil pengukuran berupa skala interval dimana obyek/kategori dapat diurutkan berdasarkan suatu atribut yang memberikan informasi 
Suroto - Efektifitas Pembelajaran Kontekstual untuk ...

tentang interval antara tiap obyek/kategori sama. Besarnya interval dapat ditambah atau dikurangi dan urutan kategori data mempunyai jarak yang sama, (Iqbal. 2004: 14).

Jenis penelitian yang digunakan pada penelitian ini adalah penelitian eksperimen dengan desain one Group Pretest-Posttest Design. Desain ini menurut Sugiyono, (2010:110) terdapat pretest sebelum diberi perlakuan sehingga bisa diketahui keakuratan perlakuan yang diberikan karena dapat membandingkan antara sebelum perlakuan dan setelah perlakuan. Senada dengan pernyataan Ibnu (2003:49) bahwa pengujian sebab akibat dilakukan dengan cara membandingkan hasil prates dengan hasil pasca tes. Desain ini hanya melibatkan satu kelompok subyek.

Subyek kelompok sebelum dikenai perlakuan tertentu diberi prates, kemudian setelah perlakuan diberikan, dilakukan pengukuran lagi untuk mengetahui akibat dari perlakuan itu. Pengujian sebabakibat dilakukan dengan cara membandingkan hasil prates dengan hasil pasca tes.

Penelitian dilakukan menggunakan populasi di Madrasah Ibtidaiyah Negeri (MIN) Malang I yang berlokasi di Jalan Bandung No. 7C Malang. Pada saat dilakukannya penelitian, jumlah peserta didik 1157 anak. Setiap jenjang kelas merupakan kelas paralel dengan jumlah kelas I - VI sebanyak 39 kelas.

Sampel yang digunakan dalam penelitian ini menggunakan sampel pertimbangan. Adapun pertimbangannya berdasarkan hasil tes yang telah dilakukan guru dimana siswa kelas VI B MIN Malang I (kelas VI terdiri dari kelas VI A sampai dengan kelas VI F) untuk materi luas bangun datar terdapat 39,3\% (11 anak dari 28 anak) yang belum mencapai ketuntasan belajar yang dipersyaratkan MIN Malang I yaitu nilai 80 .

Instrumen yang digunakan dalam penelitian ini berupa perlakuan dan pengukuran. Instrumen berupa perlakuan merupakan pemberian perlakuan pada pembelajaran yang menerapkan komponenkomponen kontekstual. Sedangkan instrumen berupa pengukuran uji validitas dan reliabilitas.

Perlakuan diberikan pada siswa kelas VIB MIN Malang I tahun pelajaran 2013/2014 berupa pembelajaran kontekstual. Pembelajaran yang dilakukan tersebut menerapkan tujuh komponen kontekstual. 
Instrumen penelitian berupa pengukuran adalah tes yang didukung dengan hasil observasi dan dokumentasi. Menurut Groundlund \& Linn, (1990:47) dan Kerlinger, (1973:442) dalam Ibnu, Mukadis dan Dasna, 2003:73 menyatakan bahwa instrumen dinyatakan memiliki kualitas yang baik bila memenuhi kriteria validitas, reliabilitas, dan praktikabilitas. Validitas instrumen diartikan sebagai kedekatan hasil pengukuran dengan keadaan yang sebenarnya. Validitas instrumen yang digunakan dalam instrumen tes pada penelitian ini adalah materi, konstruksi, dan bahasa, (Ghofur dkk. 2003:91). Ranah Materi terdiri dari dua komponen meliputi: (1) butir soal sesuai dengan indikator dan (2) batasan pertanyaan dan jawaban yang diharapkan jelas. Ranah konstruksi teridiri dari lima komponen meliputi: (1) rumusan kalimat dalam bentuk kalimat tanya atau perintah yang menuntut jawaban terurai; (2) ada petunjuk yang jelas cara mengerjakan / menyelesaikan soal; (3) ada pedoman penskorannya; (4) tabel, grafik, atau yang sejenisnya bermakna (jelas keterangannya atau ada hubungannya dengan masalah yang ditanyakan); dan (5) butir soal tidak bergantung pada butir soal sebelumnya. Sedangkan ranah bahasa terdiri dari empat komponen meliputi: (1) rumusan kalimat komunikatif; (2) kalimat menggunakan bahasa yang baik dan benar, sesuai dengan jenis bahasanya; (3) rumusan kalimat tidak menimbulkan penafsiran ganda atau salah pengertian; dan (4) menggunakan bahasa / kata yang umum (bukan bahasa lokal).

Soal yang digunakan untuk menjaring data penelitian diketahui validitasnya dengan mencermati berdasarkan komponen validitas instrumen materi, konstruksi, dan bahasa. Komponen-komponen tersebut terangkum dalam satu format yang diisi penelaah soal dengan cara memberikan tanda $(\sqrt{ })$ pada kolom yang sesuai dengan nomor soalnya.

Penentuan valid tidaknya soal tersebut dengan cara menghitung rasio banyaknya tanda $(\sqrt{ })$ pada tiap item soal terhadap seluruh komponen dan dikalikan 100. Nilai tersebut dibandingkan dengan tabel kesimpulan analisis soal seperti di bawah ini: 
Suroto - Efektifitas Pembelajaran Kontekstual untuk ...

Ketentuan kesimpulan analisis soal

\begin{tabular}{|l|l|l|}
\hline No & Kriteria & Tingkatan \\
\hline 1 & $81,00-100$ & Sangat valid atau dapat digunakan tanpa revisi \\
\hline 2 & $61,00-80,00$ & Valid atau dapat digunakan namun perlu revisi \\
\hline 3 & $41,00-60,00$ & Kurang valid, disarankan tidak digunakan \\
\hline 4 & $21,00-40,00$ & Tidak valid atau tidak boleh dipergunakan \\
\hline 5 & $00,00-20,00$ & Sangat tidak valid - tidak boleh dipergunakan \\
\hline
\end{tabular}

Soal ditelaah oleh dua orang guru matematika MIN Malang I yang masing-masing memiliki latar belakang sarjana pendidikan jurusan matematika. Hasil dari telaah butir soal pasca tes baik yang dilakukan oleh penelaah I maupun penelaah II menunjukkan bahwa soal pasca tes yang digunakan dalam penelitian ini telah memenuhi kriteria 81-100 dan digolongkan sangat valid atau dapat digunakan tanpa revisi.

Selain melakukan validasi terhadap instrumen item tes yang digunakan untuk prates dan pasca tes, validasi juga dilakukan pada Rencana Pelaksanaan Pembelajaran (RPP).

Validitas RPP dilakukan oleh dua orang guru yang juga melakukan validasi pada instrumen item tes. Lembar validasi disusun berdasarkan komponen RPP pada standar proses.

Hasil validasi terhadap RPP yang digunakan dalam penelitian dari guru I adalah 98,21. Sedangkan guru 2 adalah 100. Bila hasil tersebut dimasukkan dalam tabel ketentuan kesimpulan RPP, maka memenuhi kriteria dengan tingkatan baik sekali atau dapat digunakan tanpa revisi.

Menurut Ibnu, Mukadis dan Dasna ( 2003:74) senada dengan Thoha (2001:118-119) Reliabilitas instrumen diartikan sebagai keajegan hasil dari instrumen tersebut. Hal ini berarti suatu instrumen dikatakan reliabel manakala hasil pengukuran berkali-kali terhadap subyek yang sama selalu menunjukkan hasil yang relatif sama.

Butir tes yang digunakan dalam penelitian ini diukur dengan dengan rumus Alpha. Menurut Cronbach dalam Thoha, 2001:138140, rumus alpha digunakan untuk mengukur reliabilitas tes yang menggunakan skala likert atau tes yang menggunakan bentuk esai, (M.Chabib. 2001:138-140) Hasil penghitungan nilai $r$ didapatkan 
hasil 0,480. Berdasarkan nilai koefisien korelasi " $r$ " untuk berbagai $\mathrm{df}=26$ dengan taraf signifikansi $5 \%$ adalah 0,374 , sedangkan taraf signifikansi $1 \%$ adalah 0,478 .

$$
0,478<0,480>0,374
$$

Dengan demikian dapat diambil kesimpulan bahwa tes tersebut memiliki reliabilitas yang signifikan.

Kepraktisan atau keterpakaian yang dimaksud adalah tes yang bersifat ekonomis baik ditinjau dari sudut uang maupun waktu. Selain itu, tes juga harus mudah dilaksanakan dan diberi skor sehingga mampu menyediakan hasil yang dapat diinterpretasikan secara akurat serta dapat digunakan oleh pihak-pihak yang memerlukan (Gounlund\&Linn, 1990) dalam Ibnu, Mukadis dan Dasna ( 2003:75).

Guru menerapkan komponen-komponen pembelajaran tersebut dibuktikan berdasarkan hasil observasi kolaborator saat pembelajaran berlangsung. Kolaborator melakukan observasi pembelajaran mulai awal hingga akhir. Kolaborator dalam melakukan observasi berpandu pada pedoman observasi. Saat guru melakukan pembelajaran menerapkan komponen kontekstual, maka kolaborator memberikan tanda $(\sqrt{ })$ pada kolom "ya" di lembar pedoman observasi.

Media merupakan alat untuk membantu proses komunikasi, penyampaian pesan dari pengantar ke penerima. Meja sebagai media karena meja tersebut bermanfaat untuk membantu kelancaran pembelajaran, sedangkan meja sebagai alat peraga karena meja tersebut dapat menurunkan tingkat keabstrakan konsep.

Estiningsih (1998:20) menyatakan bahwa suatu obyek, misalnya papan tulis dapat berfungsi ganda sebagai media pengajaran, apabila papan tulis digunakan guru untuk menunjukkan bangun geometri datar yang disebut persegi panjang, maka papan tulis tersebut berfungsi sebagai alat peraga. Bila papan tulis untuk menjelaskan materi pelajaran, maka papan tulis sebagai sarana. Hal ini senada dengan Anderson dalam Ibrahim (2000:116).

Alat peraga yang digunakan dalam penelitian ini adalah meja berbagai bentuk bangun datar. Meja ini sekaligus berfungsi sebaga sarana karena dimanfaatkan siswa untuk tempat menulis. Daun meja belajar untuk siswa umumnya berbentuk persegi panjang. Meja tersebut digunakan siswa untuk menulis, membaca atau kegiatan saat 
pembelajaran berlangsung. Panjang dan lebar daun meja serta alas dan tinggi seluruhnya sama. Warna maupun bentuk meja sama untuk seluruh meja mengingat meja siswa tersebut hanya berfungsi sebagai sarana dalam pembelajaran.

Meja bentuk berbagai bangun datar yang dimaksud dalam penelitian ini memiliki bentuk dan ukuran yang berbeda. Penentuan ukuran meja didasarkan pada pertimbangan bahwa meja-meja tersebut dapat digabungkan sedemikian hingga membentuk bangun datar baru.

Tahap operasional kongkrit yang dikemukakan Piaget (7-12 tahun) merupakan masa yang paling mungkin menjadi awal perkembangan pikiran yang lebih mendalam atau lebih terintegrasi. Kemampuan membaca dan matematikanya mulai menjadi matang, kesadaran fisiknya bertambah, bahkan ia mampu menyeimbangkan diri lebih baik, selain tercapainya tingkat ekspresi diri yang baru. Rentang perhatiannya yang bertambah membantu menekuni tugas kreatifnya. Anak mengalami peningkatan pada kemampuannya menyatu dengan suatu kelompok dalam paduan suara, band sekolah, dan tim atletik, serta sebuah hasrat baru untuk memahami budaya dan kepercayaan orang lain.

Lagu merupakan upaya yang dapat digunakan untukmenemukan jati diri anak yang dapat membawanya ke kesadaran tentang emosi. Keaktifan mendengarkan musik pada anak akan melatih mereka menerima nuansa emosi yang beragam dan berlimpah di sekelilingnya. Lagu merupakan salah satu jalan menuju penerimaan pada kelompoknya. Potensi yang ada pada anak inilah yang dapat digunakan oleh guru dalam mengantarkan konsep-konsep. Salah satunya adalah matematika.

Rumus matematika dikuasai siswa memang melalui proses penemuan kembali yang dihubungkan dengan hal-hal yang ada di sekitar siswa. Setelah konsep tersebut telah dikuasai siswa, konsep perlu ditampilkan kembali untuk memecahkan masalah. Tahap menampilkan kembali menjadi salah satu masalah siswa dalam memecahkan masalah matematika. Siswa gagal menyelesaikan soal tentang luas bangun datar saat mereka lupa dengan rumus luas bangun datar yang akan dipecahkannya.

Lagu bersyair luas bangun datar merupakan upaya dalam 
memudahkan siswa menampilkan rumus luas bangun datar. Lagu yang digunakan memanfaatkan irama lagu yang disukai anakanak. Irama lagu yang digunakan pada materi luas bangun datar ini berjudul Just Give Me a Reason (Pink Feat Nate Ruess). Sedangkan syair lagu disusun peneliti yang diambil dari rumus luas bangun datar yang meliputi luas persegi panjang, segitiga, persegi, jajar genjang, layang-layang, belah ketupat, trapesium, dan luas lingkaran.

Pengumpulan data dilakukan dengan menggunakan teknik tes, observasi, dan dokumentasi. Teknik tes digunakan dengan melakukan prates dan pascates. Tes diberikan kepada siswa pada awal sebelum pembelajaran (prates) dan akhir pembelajaran (pascates).

Nilai prates dan pascates dianalisis menggunakan uji $t$ untuk mengetahui selisih derajat perbedaan antara sebelum dan sesudah mendapatkan perlakuan berupa pembelajaran kontekstual yang menggunakan media pembelajaran berupa meja berbagai bentuk bangun datar dan lagu bersyair materi luas bangun datar.

Dalam menggunakan metode observasi, cara yang paling efektif adalah melengkapinya dengan format atau blangko pengamatan sebagai instrumen. Format yang disusun berisi item-item tentang kejadian atau tingkah laku yang digambarkan akan terjadi. ${ }^{2}$ Penyusunan item-item pernyataan pada lembar observasi didasarkan pada komponen pembelajaran kontekstual.

Lembar observasi yang digunakan dalam penelitian ini terdiri dari lembar observasi aktifitas guru dan lembar observasi aktifitas siswa. Lembar observasi aktifitas guru berisi tentang seberapa jauh guru melaksanakan pembelajaran yang dilihat dari ketujuh komponen pembelajaran kontekstual. Kolaborator memberikan tanda centang $(\sqrt{ })$ pada kolom "ya" dan "tidak". Kolom "ya" dicentang saat guru melakukan pembelajaran sesuai komponen yang ada, sedangkan kolom "tidak" bila sebaliknya.

Lembar observasi siswa berisi bagaimana kondisi belajar siswa yang diamati berdasarkan ketujuh komponen pembelajaran kontekstual. Kolaborator mengamati aktifitas siswa dengan berpandu pada lembar observasi aktifitas siswa dengan memberi tanda centang $(\sqrt{ })$ pada kolom "Ya" atau "Tidak.

2 Arikunto, Suharsimi. 2006. Prosedur Penelitian. Suatu pendekatan Praktik. Jakarta: Rineka Cipta. Hal. 229. 
Foto kegiatan penelitian merupakan bukti otentik suatu kegiatan. Foto kegiatan dalam penelitian ini meliputi foto pada tahap perencanaan, dan pelaksanaan pembelajaran. Foto tahap perencanaan meliputi proses pembuatan peraga, dan diskusi antara peneliti dan kolaborator saat membahas keseluruhan penelitian. Sedangkan pelaksanaan pembelajaran meliputi aktifitas guru dan aktifitas siswa.

\section{Hasil Penelitian dan Pembahasan}

Dalam pembelajaran, peneliti mengawalinya denganmemberikan prates. Prates dilakukan dengan cara siswa mengerjakan soal uraian padalembarjawaban yang telah disediakan. Setelah siswa mengerjakan soal prates, hasil pekerjaan siswa langsung dikumpulkan tanpa dibahas oleh peneliti. Nilai prates tersebut sebagai data awal prestasi siswa sebelum diberi perlakuan berupa pembelajaran kontekstual oleh peneliti.

Kegiatan setelah prates dengan melakukan apersepsi. Apersepsi yang dilakukan guru dengan cara siswa memperhatikan model bangun datar sederhana yang ditunjukkan guru dan menyebutkan nama bangun tersebut kemudian menyebutkan rumusnya. Hal ini diulang-ulang pada 8 macam bangun datar sederhana yang meliputi persegi panjang, segitiga, persegi, jajargenjang, layang-layang, belah ketupat, trapesium, dan lingkaran.

Setiap siswa menyebutkan nama bangun datar yang ditunjukkan guru, gurulangsung membalikbangunyang baru ditunjukkan tersebut. Di balik bangun tersebut telah ditulis rumus luas bangun datarnya. Hal ini dilakukan pada semua bangun datar yang ditunjukkan guru kepada siswa.

Langkah berikutnya guru memperdengarkan lagu luas bangun datar dari laptop yang telah dihubungkan dengan sound system yang tersedia di ruang tersebut. Setiap bangun datar yang terdengar pada lagu, guru langsung mengangkat model bangun datarnya. Guru juga membagikan syair lagu luas bangun datar pada setiap siswa. Lagu tersebut terus menerus diperdengarkan selama pembelajaran dengan volume kecil sebagai latar pembelajaran, kecuali saat siswa mengerjakan soal pascates. 


\section{LUAS BANGUN DATAR}

$$
\begin{aligned}
& \text { Irama: Just Give me a reason-Pink } \\
& \text { Syair: Suroto (26 Okt } 2013 \text { 20:05) } \\
& \mid \begin{array}{llll|llll|llll|lll}
\overline{33} & \overline{33} & \overline{31} & \overline{23} & \overline{44} & \overline{44} & \overline{31} & \overline{.1} & 6 & \overline{.6} & 3 & \overline{13} & 3 & .
\end{array} .
\end{aligned}
$$





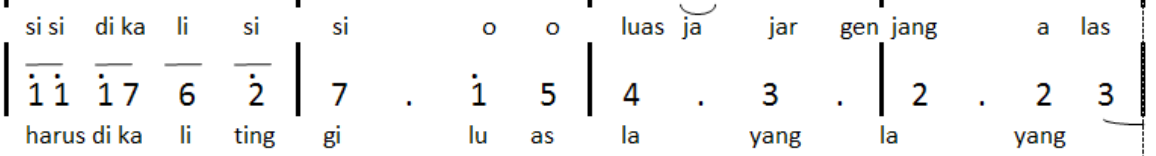

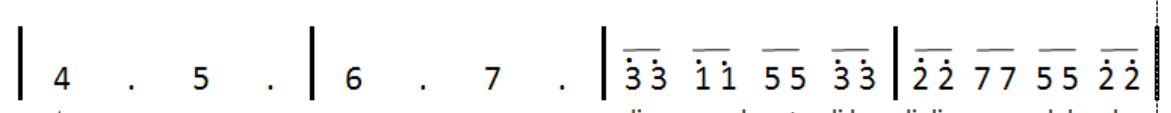



$$
\begin{aligned}
& \text { lu di bagi dua rumus ju ga tuk belah ketupat lu as tra pesi um jumlah sisi se ja jar per du }
\end{aligned}
$$

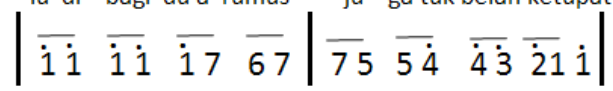

$$
\begin{aligned}
& \text { a di kali tinggi luas lingkaran pi } r \text { kuadrat }
\end{aligned}
$$

Pembelajaran dilanjutkan dengan penyampaian tujuan pembelajaran. Tujuan pembelajaran perlu diketahui siswa di awal dengan harapan agar siswa mengetahui arah dari pembelajaran yang diikutinya. Tujuan pembelajaran yang diketahui siswa di awal akan membuat siswa lebih fokus dalam belajar.

Rangkaian pembukaan dalam pembelajaran selanjutnya adalah penyampaian kegiatan selama pembelajaran. Kegiatan yang akan dilakukan perlu diketahui siswa agar mereka dapat mempersiapkan langkah pembelajaran setelah mereka mengikuti suatu tahapan. Kapan mereka harus bekerja bersama, kapan mereka harus mempresentasikan hasil kerja kelompoknya, dan kapan mereka menyelesaikan soal secara individu.

Kegiatan inti diawali dengan ditayangkannya bangun gabungan yang terbentuk dari bangun persegi panjang dan setengah lingkaran di layar LCD. Siswa mengerjakan soal tersebut bekerja sama dengan teman sebangku. Setelah selesai, hasil pekerjaan siswa dibahas secara berkelompok. 
Guru menunjukkan prosedur penyelesaian soal. Pada proses ini, guru melakukan tanya jawab tentang hal-hal yang berkaitan dengan proses yang mengarah pada prosedur. Misalnya bangun apa yang membentuk bangun gabungan tersebut, apa sajakah rumus luas bangun datar yang digunakan, dan bagaimanakah proses penyelesaian dari luas bangun gabungan tersebut. Saat ada jawaban siswa yang sesuai, maka guru menampilkannya pada LCD. Kegiatan tanya jawab ini dilakukan hingga terselesaikannya soal tentang luas tersebut.

Siswa selanjutnya dibentuk kelompok laki-laki satu kelompok dengan laki-laki, perempuan dengan perempuan. Siswa diberi kesempatan untuk memilih sendiri kelompoknya. Satu kelompok terdiri dari 4 anggota.

Saat kelompok sudah terbentuk, tiap anggota kelompok mengambil meja bangun datar yang berbeda. Salah satu anggota kelompok mengambil LKS dan model bangun gabungan di guru.

SiswamengerjakanLKS(LembarKerjaSiswa)secaraberkelompok. Guru berkeliling memperhatikan tiap-tiap kelompok dan membantu kelompok yang mengalami kesulitan dalam menyelesaikan LKS. Guru dalam memberikan bantuan pada kelompok tidak membantu memberi jawaban, tetapi dengan memberikan pertanyaan yang mengarah pada prosedur penyelesaian LKS.

Hasil pekerjaan kelompok dibahas secara klasikal dengan memberi kesempatan pada semua kelompok secara bergantian menyampaikan hasil pekerjaannya. Tiap nomor disampaikan oleh perwakilan kelompok dan dibahas secara klasikal. Bila ada jawaban kelompok yang memiliki jawaban yang kurang sesuai, maka kelompok lain diberi kesempatan untuk menyampaikan jawabannya. Guru tidak langsung menanggapi jawaban siswa yang kurang tepat, tetapi guru memberi kesempatan kepada kelompok lain untuk menanggapi jawaban tersebut. Jawaban yang telah sesuai dikuatkan oleh guru.

Kegiatan diskusi kelas ini diakhiri dengan menyanyikan lagu luas bangun datar bersama-sama dengan diperdengarkannya lagu tersebut dari sound system. Siswa menyanyi sambil melihat syair lagu luas bangun datar yang telah diterima dari guru di awal pembelajaran.

Siswa dipandu guru membuat kesimpulan dari prosedur penyelesaian soal tentang luas bangun gabungan, yaitu:(1) Menuliskan macam bangun datar sederhana pembentuk bangun gabungan 
dan mngoperasikannya; (2) Menuliskan rumus luas bangun datar sederhana pembentuk bangun gabungan; (3) Mengganti variabel pada rumus dengan ukuran pada bangun gabungan; (4) menyelesaikan kalimat terbuka pada rumus hingga terbentuk kalimat tertutup yang bernilai benar.

Siswa mengerjakan Lembar tugas secara individu untuk mengecek penguasaan mereka. Hasil pekerjaan siswa dari soal pada lembar Tugas ini sebagai data pascates yang akan dianalisis bersama dengan data prates.

Skor siswa yang diperoleh dari data prates merupakan skor awal saat siswa belum mendapatkan perlakuan berupa pembelajaran kontekstual, sedangkan skor siswa yang diperoleh dari data pascates merupakan skor setelah siswa mendapatkan perlakuan berupa pembelajaran kontekstual.

Siswa yang digunakan dalam penelitian adalah 27 anak. Nilai siswa dari hasil prates masih sangat tidak memuaskan terbukti bahwa nilai rata-rata prates hanya 46,48 . Nilai terendah hanya 13 dan nilai tertinggi 87 . Sedangkan nilai pascates memiliki rata-rata 78,74 dan nilai tertinggi 100 yang menunjukkan peningkatan dari nilai prates. Hal ini berarti prestasi siswa setelah mendapatkan perlakuan pembelajaran kontekstual mengalami peningkatan.

Penelitian yang telah dilakukan ini telah menghasilkan bukti bahwa pembelajaran kontekstual dapat meningkatkan prestasi belajar siswa kelas VI B MIN Malang I pada tahun pelajaran 2013/2014. Keberhasilan ini disebabkan oleh adanya upaya menerapkan komponen-komponen pembelajaran kontekstual dalam pembelajaran.

Setiap komponen pembelajaran kontekstual dijadikan titik tolak dalam menyusun Rencana Pelaksanaan Pembelajaran (RPP) serta digunakan dalam melaksanakan pembelajaran. RPP disusun dengan berpandu pada penjabaran komponen-komponen kontekstual sehingga keseluruhan langkah pembelajaran betul-betul mencerminkan pembelajaran kontekstual secara utuh.

Selain pengendalian rencana dan proses pembelajaran, keberhasilan penggunaan model pembelajaran kontekstual ini juga diamati dari sisi efektifitasnya. Hasil prates dan pascates diamati tingkat perbedaannya menggunakan serangkaian analisis data yang 
Suroto - Efektifitas Pembelajaran Kontekstual untuk ...

menggunakan uji t.

Data prates dan pascates siswa pada penelitian ini tidak hanya diamati ukuran tendensi sentral saja. Namun juga diolah menggunakan analisis data uji t. Setelah serangkain penghitungan dilakukan, telah menghasilkan $\mathrm{t}_{0}=-11,549$ (tanda minus bukanlah tanda aljabar, karena itu dibaca: ada selisih derajat perbedaan sebesar 11,549). Hasil penghitungan tersebut dikonsultasikan dengan harga kritik $\mathrm{t}$ taraf signifikansi 5\% sebesar 2,06 dan taraf signifikansi 1\% sebesar 2,78 dengan berpegang pada $\mathrm{df}=26 . \mathrm{T}_{\text {hitung }}$ diinterpretasikan terhadap $t_{\text {tabel }}$, ternyata $2,06<11,549>2,78$ berarti antara prates dan pascates memiliki perbedaan yang signifikan.

Efektifitas pembelajaran kontekstual yang dimaksud dalam penelitian ini dititikberatkan pada diterapkannya komponenkomponen pembelajaran kontekstual pada tahapan-tahapan pembelajaran mulai tahap pembukaan hingga tahap penutup. Guru yang bertindak sebagai penyaji pembelajaran yang selanjutnya disebut guru, melakukan pembelajaran dan diamati oleh guru kelas VI B yang selanjutnya disebut kolaborator. Guru dalam melakukan pembelajaran diamati oleh kolaborator mulai awal hingga akhir pembelajaran.

Perbedaan yang signifikan ini terjadi karena pembelajaran yang dilakukangurutelahmenerapkankomponen-komponenpembelajaran. Guru dalam melakukan pembelajaran telah menguatkan komponenkomponen kontekstual dengan cermat sehingga siswa diposisikan sebagai subyek belajar. Siswa menguasai konsep luas gabungan bangun datar sedikit demi sedikit melalui proses yang dialaminya.

Siswa mengalami pengembangan penguasaan hasil belajar secara bertahap pada ranah kognitif mulai pengetahuan, pemahaman, analisis, sintesa, hingga evaluasi melalui kegiatan bertanya, menemukan, pemodelan, refleksi melalui penilaian sebenarnya (authentic assessment) yang dilakukan guru.

Pada ranah afektif, siswa menerima, menanggapi, menilai, mengelola, dan menghayati proses pembelajaran secara optimal hingga mereka menyadari penguasaan konsep yang telah mereka pelajari melalui refleksi dan kesimpulan. Hal ini diharapkan agar konsep yang telah dikusai siswa dapat dimanfaatkan untuk memecahkan masalah yang berkaitan dengan luas gabungan bangun datar. 
Pada ranah psikomotor, siswa melakukan peniruan melalui pemodelan prosedur penyelesaian luas gabungan bangun datar, melakukan manipulasi proses melalui masyarakat belajar yang diciptakan guru saat siswa mengerjakan LKS. Siswa mendemonstrasikan membentuk dua meja bangun datar sederhana menjadi bangun gabungan dan menghitung luasnya.

Pembelajaran kontekstual yang diterapkan guru tersebut telah memfasilitasi siswa dalam menguasai konsep luas gabungan bangun datar pada ranah kognitif, afektif maupun psikomotor.

\section{Kesimpulan}

Kesimpulandaripenelitianiniadalah:1)Pembelajarankontekstual efektif digunakan dalam menyampaikan pelajaran matematika materi luas bangun datar dengan menerapkan komponen pembelajaran kontekstual yang terdiri dari; a) Konstruktivisme (Constructivism), b) Bertanya (Questioning), c) Menemukan (Inquiry), d) Masyarakat belajar (Learning Community), e) Pemodelan (Modeling), f) Refleksi (Reflection), dan g) Penilaian sebenarnya (Authentic Assessment); 2) Prestasi belajar matematika materi luas bangun datar siswa kelas VI MIN Malang I mengalami perbedaan antara sebelum dan sesudah menggunakan pembelajaran kontekstual. Sebelum digunakan pembelajaran kontekstual, nilai rata-rata prates 46,5 . Setelah siswa diberi perlakuan berupa pembelajaran kontekstual, nilai pascates 78,7. Hasil penghitungan uji t menghasilkan -11,549 (dibaca ada selisih derajat perbedaan 11,549). Nilai ini lebih besar daripada $t_{\text {tabel }}$ baik pada taraf signifikansi 5\% sebesar 2,06 maupun 1\% sebesar 2,78.

Berdasarkan kesimpulan tersebut dikemukakan beberapa implikasi yang dianggap relevan dengan penelitian ini. Implikasi tersebut adalah sebagai berikut: 1) Pembelajaran kontekstual dapat digunakan dalam pembelajaran matematika materi luas gabungan bangun datar di kelas VI. Pembelajaran ini khususnya menguatkan komponen pembelajaran; 2) Pembuatan soal perlu berpandu pada persyaratan telaah butir soal agar soal yang terbentuk memiliki tingkat validitas isi, konstruksi, dan bahasa; 3) Hasil belajar siswa perlu diolah guru untuk mengetahui tingkat reliabilitasnya agar diketahui tingkat perbedaan antara sebelum dan sesudah diberi perlakuan pembelajaran oleh guru; 4) Pembelajaran hendaknya menggunakan media dan alat peraga agar siswa lebih mudah mencerna materi yang dipelajarinya. 
Suroto - Efektifitas Pembelajaran Kontekstual untuk ...

\section{DAFTAR PUSTAKA}

Arikunto, Suharsimi. 2006. Prosedur Penelitian. Suatu pendekatan Praktik. Jakarta: Rineka Cipta.

Azwar, Saifuddin. 2013. Tes Prestasi. Fungsi dan Pengembangan Pengukuran Prestasi Belajar. Yogyakarta: Pustaka Pelajar.

Dimyati dan Mujiono. 2009. Belajar dan Pembelajaran. Jakarta: Rineka Cipta.

Don Campbell. 2002. Efek Mozart Bagi Abak-Anak. Meningkatkan Daya Pikir, Kesehatan, dan Kreatifitas Anak Melalui Musik. Alih bahasa: Alex Tri Kantjono Widodo. Jakarta: Gramedia.

Ghofur dkk. 2003. Pola Induk Pengembangan Sistem Penilaian. Surabaya: Dinas Depdikbud Sub Din Dikmenum.

Hasan, Iqbal. 2004. Analisis Data Penelitian dengan Statistik.Jakarta: Bumi Aksara.

Hergenhahn, B.R. 2012. Theories of Learning (Teori Belajar). Terjemahan Triwibowo B.S. Jakarta: Kencana Prenada Media Group.

Hull's D., \& Souders, Jr., J.C. (1996, October). The Coming Challenge: Are community colleges Ready for the New Wave of Contextual Learners?. Community College Journal. 67, (2).

Kartika Wandini. 2008. Pengaruh Pola Asuh Belajar, Lingkungan Pembelajaran, Motivasi Belajar Dan Potensi Akademik Terhadap Prestasi Akademik Siswa Sekolah Dasar. http://repository. ipb.ac.id/bitstream/handle/12345 6789/2038/A08kwa. pdf? sequence=5. Diakses 15 November 2013. 18:54.

Menteri Pendidikan dan Nasional. 2006. Lampiran Permendiknas Nomor 22 Tahun 2006 tentang Standar Isi untuk Satuan Pendidikan Dasar dan Menengah.

Menteri Hukum dan HAM. 2013. Peraturan Pemerintah Republik Indonesia Nomor 32 Tahun 2013Tentang Perubahan Atas Peraturan Pemerintah Nomor 19 Tahun 2005 Tentang Standar Nasional Pendidikan.

Menteri Pendidikan dan Kebudayaan. 2006. Peraturan Menteri Pendidikan Nasional nomor 22 Tahun 2006 tentang Standar Isi Untuk Satuan Pendidikan Dasar dan Menengah. 
Nidlomun Ni'am. 2013. Belajar dan faktor yang mempengaruhinya. . Diakses 15 November 2013 19:46.

Nurhadi dan Senduk, Agus Gerrad. 2009. Pembelajaran Kontekstual. Surabaya: Jepe Press Media Utama.

Pusat Bahasa Depdiknas. 2008. Kamus Besar Bahasa Indonesia..

Santrock, John W. 2011. Psikologi Pendidikan. Dialihbahasakan oleh Tri Wibowo BS. Jakarta: Kencana Prenada Media Grup.

Slameto. 2010. Belajar dan Faktor-Faktor yang Mempengaruhi. Jakarta: Rineka Cipta.

Sugiono. 2010. Metode Penelitian Pendidikan. Pendekatan Kuantitatif, Kualitatif, dan RED. Bandung: Alfabeta.

Thoha, M.Chabib. 2001. Teknik Evaluasi Pendidikan. Jakarta: Raja Grafindo Persada.

Tu'u,Tulus.2004.Peran Disiplin pada Perilaku dan Prestasi Siswa. Jakarta: Rineka Cipta. 
